\title{
German Colonists in the Migration Policy of the Russian Autocracy (Analysis of the Laws of the Russian Empire)
}

\author{
Olga V. Erokhinaa, Olga A. Litzenbergerb \\ aMoscow Pedagogical State University; 88,Vernadskogo Av., Moscow, 119571, Russia; \\ ov.erokhina@mpgu.su \\ bBavarian Cultural Centre for Germans from Russia; \\ 20a, Sand str., Nuremberg, 90443, Germany; litzenbergerolga@gmail.com
}

\begin{abstract}
The article traces the policy of resettlement of German nationals from German states to the southern outskirts of the Russian empire based on the analysis of legislative material. To analyze the laws of the Russian Empire, the authors use historical-comparative and historical-systemic methods. Analysis. Mostly farmers were invited to Russia. They were to contribute to the transfer of improved European agricultural practices to the Russian peasantry. However, the Russian authorities could not predict the possible consequences of inviting foreigners. Therefore, there was no clear mechanism for organizing and regulating this process. Immigrants were offered significant benefits and privileges, so they agreed to move. Over time, the overpopulation of the colonies due to the high birth rate and lack of land contributed to the beginning of migration movements of the Germans in the second quarter of the XIX century in various regions of Russia from the mother colonies. The geography of the colonists began to expand as new laws were passed that eventually regulated their way of life. They created new colonies in the image of their mothers in the Caucasus and the Don, Siberia and Central Asia. The loss of benefits and privileges led not only to an increase in migration processes among them, but also forced them to emigrate to America and even return to Germany. Empire

Keywords: immigration, emigration, German colonist, resettlement policy, migration, Russian

For citation: Erokhina, Olga V., and Litzenberger, Olga A. "German Colonists in the Migration Policy of the Russian Autocracy (Analysis of the Laws of the Russian Empire)." RUDN Journal of Russian History 19, no. 4 (November 2020): 810-823. https://doi.org/10.22363/2312-8674-2020-19-4-810-823

\section{Немецкие колонисты \\ в миграционной политике российского самодержавия (анализ законов Российской империи)}

\section{О.В. Ерохина, О.А. Лиценбергер}

аМосковский педагогический государственный университет; 119571, Россия, Москва,

Проспект Вернадского, д. 88; ov.erokhina@mpgu.su

bБаварский центр культуры немцев из России; 90443, Германия, Нюрнберг;

litzenbergerolga@gmail.com
\end{abstract}

\begin{abstract}
Аннотация: На основе анализа законодательно-актового материала прослеживается проведение политики переселения немецких подданных из германских государств на южные окраины Российской империи. Авторами в качестве основных методов используются историко-сравнительный и историко-системный. Следует отметить, что в Россию приглашались в основном земледельцы. С их помощью власти собирались не только защищать земли от набегов кочевых племен, но и надеялись осваивать пустующие территории. Кроме того, переселенцы должны были способствовать передаче российскому крестьянству улучшенного европейского опыта ведения сельскохозяйственных
\end{abstract}

(C) Erokhina O.V., Litzenberger O.A., 2020

cc (i) This work is licensed under a Creative Commons Attribution 4.0 International License https://creativecommons.org/licenses/by/4.0/ 
работ. Однако российские власти не могли спрогнозировать возможных последствий приглашения иностранцев и такого количества желающих поселиться в России. Поэтому не было продумано четкого механизма организации и регулирования этого процесса. Чтобы немецкие подданные согласились переезжать, им предлагались значительные льготы и привилегии для обустройства на месте. Со временем удалось урегулировать многие противоречия и конфликты во взаимоотношениях местных властей и переселенцев. В конечном итоге перенаселенность колоний вследствие высокой рождаемости и нехватка земель способствовали началу миграционных движений немцев во второй четверти XIX. в различные регионы России из материнских колоний. Бывали случаи, когда они самовольно покидали места приписки в поисках свободных земель и лучшей доли. Со временем география расселения колонистов будет постоянно расширяться по мере принятия новых законов, регулировавших их образ жизни. Они создавали новые колонии по образу материнских колоний на Кавказе и Дону, в Сибири и Средней Азии. Потеря льгот и привилегий приводила не только к усилению миграционных процессов в их среде, но и вынуждала их эмигрировать в Америку и даже возвращаться в Германию.

Ключевые слова: иммиграция, эмиграция, немецкий колонист, переселенческая политика, миграция, Российская империя

Для цитирования: Ерохина O.B., Лиценбергер О.A. Немецкие колонисты в миграционной политике российского самодержавия (анализ законов Российской империи) // Вестник Российского университета дружбы народов. Серия: История России. 2020. Т. 19. № 4. С. 810-823. https://doi.org/10.22363/2312-8674-2020-19-4-810-823

\section{Introduction}

People have always migrated. Regardless of when or where, people have moved vast distances in search of safety or prosperity. The phenomenon certainly played an essential role in the emergence, formation, and development of ethnic German communities in Russia. Furthermore, once having arrived, they did not necessarily stay put and their continuous resettlement has given them a unique place in the Russian mentality as a "Volk auf dem Weg" (People on the Move). Their history is key to understanding the current resettlement profile of both Germans and other ethnic groups in Russia today.

To analyze the changes that took place in the migration policies the Russian state adopted for German colonists, as well as to appreciate their interconnection and interdependence, the authors reviewed the relevant legislation using the historical-comparative and historical-systemic methods. Their primary sources include laws beginning with the colonists' invitation to Russia in the middle of the $18^{\text {th }}$ century to the late $19^{\text {th }}$, which are published in the Complete Collection of Laws of the Russian Empire (Polnoe sobranie zakonov Rossiyskoy imperii, or PSZ RI).

\section{Legislative acts aimed at organizing foreign colonies in the Russian Empire}

Until the early $18^{\text {th }}$ century, Russian rulers strove to develop their vast Ural and Siberian lands, which they primarily carried out by colonization. However, few of their subjects were available because so many were tied to estates in European Russia by serfdom.

From the second half of the $18^{\text {th }}$ century, Russia needed to develop great expanses in the south and southeast of the country that had recently been incorporated into the empire. The reign of Elizabeth Petrovna already witnessed the settlement of Serbian colonists on the Dnieper's River's eastern bank, and this served as a basis for further widescale invitations to foreigners to settle in Russia ${ }^{1}$. Catherine II likewise understood this, noting, "It is a vain hope that we cherish to see help from the children who can be born in future in order to revive our Power, lacking inhabitants. We should abandon this hope as people who live in their deserts have neither inspiration, not diligence..."2

\footnotetext{
${ }^{1}$ M.K. Lyubavskiy, Obzor istorii russkoy kolonizatsii (Moscow: Moskovskiy universitet Publ., 1996), 280.

2 Orden imperatritsy Yekateriny II, vruchennyy Komissii po sostavu proyekta novogo Kodeksa (St. Petersburg: Tipografiya Imperatorskoy Akademii nauk Publ., 1907), 181.
} 
But where were people be found to settle the empire's southern frontier? Count P.I. Panin suggested inviting foreigners to these empty lands "by granting them plots of land with the rights of owners and free entrepreneurs." "The preference for Germans was not arbitrary. By the 1760s, "In the German land, many craftsmen were in the desperate financial situation, lost their homes ... Others have been so impoverished that they have been forced to seek food, shelter and support in nearby towns..."4 Historians also point out other reasons, such as avoiding conscription, oppression, and religious prosecution. ${ }^{5}$

On July 22, 1763, Catherine II called for foreigners to move to Russia and granted them substantial benefits, including freedom of religion and permission to build churches; exemption from taxes and duties from 5 to 30 years, depending on the place of settlement, as well as from obligatory military and civil service; ten-year interest-free loans; and duty-free import of goods worth up to 300 rubles. $^{6}$

The colonists were initially accommodated at temporary collection centers outside St. Petersburg where they could learn more about Russian laws and traditions and pledge allegiance to the Russian throne. At the same time, officials carried out discussions and interviews to obtain their consent to settle down in the areas specified in the Register (mainly on the Volga), thereby violating earlier promises to let immigrants freely choose where they could settle, including the capital.

Many European countries fiercely opposed the recruitment of potential colonists by Russian missions. Bavaria, Prussia, Pfalz, Saxony, Sweden, and others expressly banned the publication of the manifesto in their countries. The Austrian Empire, which also actively encouraged immigration, imposed sentences of five years in prison and penal labor for violators. However, private recruiters, or vyzyvateli, generally ignored such official prohibitions. Their greed for profit - the recruiters were paid a for each new colonist and the absence of proper controls, not to mention an often poorly organized resettlement process, resulted in many abuses and breaches, ranging from forging witness signatures to diverting the money allocated for colonist transportation to the pockets of the vyzyvateli. ${ }^{7}$

In the Volga region, the authorities planned to settle the colonists in districts (okrug) based on their confession to avoid "any kind of hostility and hatred that tends to

${ }^{3}$ V.G. Chebotareva, "Nemetskie kolonii v real'noy situatsii krepostnicheskoy Rossii: politika paternalizma po otnosheniyu k nemetskim krest'yanam," in Nemtsy Rossii: evolyutsiya istoricheskogo puti (1762 g. $X X$ v.) (Moscow: Mezhdunarodnyy Soyuz obshchestvennykh ob"yedineniy nemtsev, Obshchestvennaya akademiya nauk rossiyskikh nemtsev Publ., 2012), 14.

4 "Mneniye senatora A.B. Buturlina ob organizatsii priyema inostrannykh kolonistov v Rossii," in Nemtsy kolonisty v Vek Yekateriny (Moscow: Drevlekhranilishche Publ., 2004), 166-167.

${ }^{5}$ N.E. Vashkau, Shkola v nemetskikh koloniyakh Povolzh'ya. 1764-1917 (Volgograd: Volgogradskiy Gosudarstvennyy universitet Publ., 1998); L.V. Malinovskiy, Istoriya nemtsev v Rossii (Barnaul: BGPU, 1995); N.V. Venger, Mennonitskoye predprinimatel'stvo v usloviyakh modernizatsii yuga Rossii: mezhdu kongregatsiyey, klanom i rossiyskim obshchestvom (1789-1920) (Dnepropetrovsk: Dnepropetrovskiy natsional'nyy universitet Publ., 2009); T.N. Chernova-Doke, Nemetskiye poseleniya na periferii Rossiyskoy imperii: Kavkaz: vzglyad skvoz' stoletiye (1818-1917). (K 190-letiyu osnovaniya nemetskikh koloniy) (Moscow: Mezhdunarodnyy soyuz nemetskoy kul'tury Publ., 2008); A. Bosch, Dr. Geschichte in Gedichten und Prosa. Auswanderung aus Franken an die Wolga (Nürnberg: [S.n.], 2016); O. von Luchterhandt, A. Eisfeld, Die Russlanddeutschen in den Migrationsprozessen zwischen den GUS-Staaten und Deutschland (Göttingen: Göttinger Arbeitskreis, 2008); O. Larina , V. Shaidurov, "European diasporas in Russia of the late $18^{\text {th }}$ and early $19^{\text {th }}$ centuries: National and regional formation features (as illustrated in the case of Jews, Germans and Poles)," Mediterranean Journal of Social Sciences 6, no. 5 (2015): 460-466.

6 "O dozvolenii vsem inostrantsam, v Rossiyu v"yezzhayushchim, poselyat'sya v kotorykh Guberniyakh oni pozhelayut i o darovannykh im pravakh № 11.880,” in Polnoe sobranie zakonov Rossiyskoy imperii. Collection 1. Vol. 16 (St. Petersburg: Tipografiya II Otdeleniya Sobstvennoy E. I. V. Kantselyarii Press., 1830), 313-316.

${ }^{7}$ W. Funk, "Deutsche als russische Kolonisten," in Blätter für fränkische Familienkunde (Nürnberg: [S.n.], 1929), 102. 
arise between people of different faiths due to the excessive religious zeal." 8 But this proved impossible to carry out in practice. Nevertheless, over time the colonies managed to form religiously homogeneous communities. ${ }^{9}$

Another problem was the number of additional colonists the Russian government was prepared to accept, based on the mistaken idea of handing over the subsequent arrangement of foreign settlements to the vyzyvateli. As a result, the inflow of colonists exceeded all expectations. When they invited foreigners to Russia, officials failed to predict that their numbers would rise dramatically from year to year. As a consequence, they were no longer able to cope with the ever growing influx of immigrants, and in 1766 had to announce a temporary ban "until all the colonists who had come so far received homes, implements, tools, livestock and all other items required for their needs, and until they actually started working to have their own daily bread." ${ }^{10}$ However, in the context of rising international tensions and despite Russia's official announcement of the halt in immigration, many private recruiters continued their work for another six months.

In considering the development of her state, Catherine II wrote that with their "works, activities, trades, handicraft factories and manufactories, the colonists can bring equal benefits to the vast... Empire in the short term." 11 The colonists were provided with 30 dessiatin $(1$ dessiatin $=2.7$ acres $)$ of land to cultivate. ${ }^{12}$ Despite the fact that the government's main reason for its resettlement policy was to develop Russia's steppe frontier, some 10 to 20 percent of those the vyzyvateli had recruited did not know how to farm. ${ }^{13}$

Furthermore, upon arrival the colonists faced many problems, such as inadequate plots, poor soil, not knowing how to farm in anew climate, and the lack of proper accommodations. For example, in 1769 only 4,560 houses were ready for the 6,433 families in the first group to arrive in the Volga region, and four years later 5,963 houses had been built for 6,175 families. ${ }^{14}$ The next group of new colonists included Mennonites, who were granted the same rights and privileges as the Volga colonists, but received more than double the land per family as the earlier immigrants: 65 dessiatin of usable land and another 65 dessiatin that were unsuitable for farming. ${ }^{15}$ At the beginning of 1789, 228 families arrived and settled in Ekaterinoslav Province, followed by another 118 in 1793-1796. ${ }^{16}$

Alexander I followed his grandmother's colonization policy. He issued more than 15 decrees and resolutions regarding both newly arrived and established colonists and their allotments. Invited to emigrate to his empire, Mennonites and those of other confessions were offered new homesteads in the Novorossiisk Krai. At the same time, officials were obligated to ensure that "these people knew no want for anything and that, contrary to

8 "Vysochayshe utverzhdennyy doklad Pravitel'stvuyushchego Senata o razmezhevanii zemel', otvedennykh dlya poseleniya inostrannykh kolonistov, s prilozheniyem donosheniya prezidenta kantselyarii opekunstva inostrannykh grafa G.G. Orlova № 12.095," in Polnoe sobranie zakonov Rossiyskoy imperii, 654.

${ }^{9}$ O. Litzenberger, Deutsche evangelische Siedlungen an der Wolga (Nürnberg: [S.n.], 2013); Ibid.

10 "Vysochayshe Utverzhdennoye ob"yavleniye zhelayushchim vykhodit' v Rossiyu na poseleniye inostrantsam № 12.793,” in Polnoe sobranie zakonov Rossiyskoy imperii. Vol. 17, 1067.

${ }^{11}$ G.G. Pisarevskiy, Izbrannyye proizvedeniya po istorii inostrannoy kolonizatsii v Rossi (Moscow: MSNK Publ., 2011), 164.

12 “O razmezhevanii zemel', naznachennykh dlya poseleniya v"yezzhayushchikh inostrantsev № 12.095," in Polnoe sobranie zakonov Rossiyskoy imperii. Vol. 16, 650.

${ }^{13}$ Einwanderung in das Wolgagebiet: 1764-1767 (Göttingen: Göttingenger Arbeitskreis, 1999, 2001, 2005, 2008).

${ }^{14}$ Yu.S. Gal'perina, "Economic development of the German colonies on the Volga in the second half of XVII - the first half of the XX century," Saratov University Bulletin. History. International relationships 14, no. 3 (2014): 99.

15 G.G. Pisarevskiy, Izbrannye proizvedeniya po istorii inostrannoy kolonizatsii v Rossii (Moscow: MSNK Publ., 2011), 164.

${ }^{16}$ A. Klaus, Nashi kolonii. Opyty i materialy po istorii i statistiki inostrannoy kolonizatsii v Rossii (St. Petersburg: tip. V.V. Nusval'ta Publ., 1869), 117. 
expectations, they were not left in destitution as was the case with the colonists earlier brought to Russia."17

Minister of the Interior V.P. Kochubei introduced some amendments to the government's resettlement policy. He pointed out that the existing practice encouraged the immigration of "bad farmers," including unwanted artisans, senile and weak people and, making matters worse, very poor ones. Therefore, the minister argued that it would be more expedient to invite "good and well-to-do farmers," who wielded "all the best agricultural knowledge."18 For this reason, at the request of the City of Taganrog's governor, B.B. Campenhausen, L. von Trefurtov sent artisans from Danzig to his city in $1808 .{ }^{19}$

Kochubei's changes also limited the number of new immigrants to 150 families every year, and they were expected to bring along starting capital or goods worth at least 300 guilders. Each household was allotted a 65 dessiatin land plot and 300 rubles to build a house and start work. He also ensured that earlier colonists enjoyed the same benefits. ${ }^{20}$ For the first time the government invited farmers as well artisans useful for rural life, such as tailors, shoemakers, carpenters, blacksmiths, potters, tinkers, weavers and stonemasons.

On March 1, 1804, a decree was issued allowing colonists to buy land in the Novorossiisk Krai. This benefitted Mennonites who left Prussia for religious reasons. L. von Trefurtov, the Russian Consul in Danzig, reported that more than 300 families applied for permission to resettle. He added that most of them were financially secure and brought livestock of good breed with them. According to the estimates of the Ministry of State Property, colonists imported 450,000 rubles in silver to Russia between 1804 and $1806 .{ }^{21}$

In 1810, the committee charged with finding savings in state spending advised Alexander I that paying for the colonists' transportation and household arrangements was a major drain on the treasury. It cost more than 5,000 rubles to resettle one colonist family, while this amount was enough to resettle about50 Russian peasants. ${ }^{22}$ On February 25, 1810 these findings were followed by the decree "On discontinuing loans to colonists." Offering no money for resettlement, the government promised to protect those who immigrated to Russia at their own expense and guaranteed them lands and privileges. In August 1819, the authorities announced they cancelled the policy of inviting foreigners to Russia. ${ }^{23}$ That October, Russian diplomatic missions received orders banning the issue of passports to foreigners, ${ }^{24}$ which led to a decline in immigration but failed to stop it entirely. ${ }^{25}$

The last decree on mass immigration of Mennonites to the Russian Empire was published in $1859,{ }^{26}$ which entirely eliminated any incentives to settle in Russia. According

${ }^{17}$ Pis'ma gertsoga Armana Emmanuila de Rishel'ye Samuilu Khristianovichu Konteniusu 1803-1814 gg.: s prilozheniyem dokumentov (Odessa: TES Publ., 1999), 205-206.

18 “O pravilakh dlya prinyatiya i vodvoreniya inostrannykh kolonistov № 21.163," in Polnoe sobranie zakonov Rossiyskoy imperii. Vol. 28, 137-140.

19 O.V. Erokhina, Nemetskiye kolonii Oblasti Voyska Donskogo (vtoraya polovina XIX v. - fevral' 1917 g.) (Volgograd: Volgogradskoye nauchnoye izdatel'stvo Publ., 2009), 47-48.

${ }^{20}$ Ibid., 137.

21 "History and statistics of colonies of foreign settlers in Russia," Journal of the Ministry of state property, no. 10 (1854): 15.

22 “O prekrashchenii vydachi denezhnoy ssudy kolonistam № 24131,” in Polnoe sobranie zakonov Rossiyskoy imperii. Vol. 31, 69.

23 “O presechenii dal'neyshego pereseleniya v Rossiyu inostrannykh vykhodtsev № 27912," in Polnoe sobranie zakonov Rossiyskoy imperii. Vol. 31, 325.

24 “O zapreshchenii Rossiyskim missiyam davat' pasporty pereselyayushchimsya v Rossiyu i v Tsarstvo Pol'skoye inostrantsam № 27.954," in Polnoe sobranie zakonov Rossiyskoy imperii. Collection 2. Partition 1. Vol. 31 (St. Petersburg: Tipografiya II Otdeleniya Sobstvennoy E. I. V. Kantselyarii Press., 1857), 362.

${ }^{25}$ J. Stach, Die deutschen Kolonisten in Süd-Russland (Prischib: [S.n.], 1904), 23.

26 "O poselenii Prusskikh mennonistov na Samarsko-Stavropol'skikh zemlyakh № 34077a," in Polnoe sobranie zakonov Rossiyskoy imperii. Collection 2. Partition 1. Vol. 34 (St. Petersburg: Tipografiya II Otdeleniya Sobstvennoy E. I. V. Kantselyarii Press., 1861), 494-497. 
to A.A. Verigin's statistics on Germans immigration, more than 130 colonies were founded between 1764 and 1800 . The number more than doubled to 272 over the next 50 years, and about 150 more from 1850 to $1864 .{ }^{27}$ By 1917 , there were 2,068 German settlements and resettlements ${ }^{28}$ in the empire. ${ }^{29}$

\section{Internal migration processes of the second half of the XIX - early XX century}

The rising number of colonies in Russia after 1850 was no longer due to Germans arriving from their fatherland. Instead, it was attributable to migration among Germans to other provinces, which occurred much earlier than the government's efforts to encourage peasant resettlement within Russia. K.E. Lindeman noted, "As the population in the colonies multiplied, the land plots allocated to them became smaller and less sufficient, which led to a need to expand these original plots. The government accordingly settled recent arrivals in recently established colonies and allotted them new plots on the same favorable terms as for the original colonies." ${ }^{30}$

Catherine II decreed the first law to encourage internal migration on August 17, 1793. She allowed 270 colonists from the Petersburg colonies to move to Ekaterinoslav Province and permitted them to sell "houses and other buildings... that they cannot take with them... for their own benefit." ${ }^{31}$ On April 6, 1800, Paul I approved a Senate report stating that, of 314 Mennonite families in Khortitsa, 150 had been resettled to another plot of fertile land the treasury had bought. ${ }^{32}$

Such internal migration was due to overpopulation in the original colonies and the resulting land hunger, as well nomadic raids from the steppe. Birth rates among the German colonists grew rapidly. By the middle of the $19^{\text {th }}$ century they averaged $2.43 \%$ every year in the Lower Volga region - the highest in the empire - reaching $7.1 \%$ and $6.3 \%$ per annum in the Kamyshinand Novouzenskii Uezds, respectively. This resulted in smaller plots per person. If there were 20 dessiatin per male in Samara Province in 1795 , their area declined to15 dessiatin in 1833 and 6.5 dessiatin in $1858 .{ }^{33}$ The situation was similar in many other German colonies.

Beginning in the 1830 s, these scarcities gradually increased migration within Russia. Colonists moved to neighboring plots or to those in other provinces, which they bought at their own expense, sometimes with financial support from the government. The first to do so were colonists in Chernigov Province who decided to resettle in Ekaterinoslav Province because of the land shortage. The authorities provided them with 60 dessia-

27 A.A. Velitsyn, Nemtsy v Rossii. Ocherki istoricheskogo razvitiya i nastoyashchego polozheniya nemetskikh koloniy na yuge i vostoke Rossii (St. Petersburg: Russkiy vestnik Publ., 1893), 51-54.

${ }^{28}$ A "mother" colony is a settlement founded by migrants who came to Russia from European countries; a "daughter" colony is a settlement founded after part of the "mother" colony population resettled in another region or on neighboring lands separated from the original ones.

29 K.E. Lindeman, Prekrashcheniye zemlevladeniya $i$ zemlepol'zovaniya poselyan-sobstvennikov. Ukazy 2 i 13 dekabrya 1915 g. i 10, 15 iyulya i 19 avgusta 1916 g. i ikh vliyaniye na ekonomicheskoye sostoyaniye yuzhnoy Rossii (Moscow: K.L. Men'shov Press., 1917), 131.

${ }^{30}$ Ibid., 127.

31 "O pereselenii 270 dush kolonistov iz Yamburgskogo uyezda v Yekaterinoslavskuyu Guberniyu; o pribavke pashennoy zemli ostayushchimsya $\mathrm{v}$ onom uyezde kolonistam; o dache im l'goty na fevralya pyat' let, i o sravnenii ikh, po proshestvii sego vremeni, v platezhe podatey s Izhorskimi kolonistami № 17.147," in Polnoe sobranie zakonov Rossiyskoy imperii. Collection 1. Vol. 23, 454.

32 "O predpolagayemykh sredstvakh k popravleniyu sostoyaniya Novorossiyskikh inostrannykh poselentsev i ob uchrezhdenii pod vedomstvom Ekspeditsii gosudarstvennogo Khozyaystva, Kontory Opekunstva Novorossiyskikh inostrannykh poselentsev № 19.372," in Polnoe sobranie zakonov Rossiyskoy imperii. Collection 1. Vol. 26, 119-122.

${ }^{3}$ Ye.V. Ananyan, Nemtsy Povolzh'ya: ot immigratsii k emigratsii (1760-1880-ye gg.). Dva s polovinoy veka s Rossiyey ( $k$ 250-letiyu nachala massovogo pereseleniya nemtsev v Rossiyu): Materialy 4-y mezhdunarodnoy nauchno-prakticheskoy konferentsii (Moscow: Gotika Publ., 2013), 211. 
tin per person and granted a five-year exemption from taxes and duties on the condition that they "arrange the resettlement at their own expense." "34

Unauthorized resettlement of colonists also took place. In the 1820s, some Volga Germans moved to Orenburg Province without official permission, while others went to the Mineral Waters region in the Caucasus. To stem the exodus the government created the position of special supervisor (smotritel') in 1825, and colonists could only move with formal approval. ${ }^{35}$

In 1828, I.F. Paskevich reported to the Ministry of the Interior that "the Saratov colonists" were living in the Scottish colony of Karras, ${ }^{36}$ but argued that their presence there was "useful, and, to help the new arrivals with their basic living needs," he proposed "cutting the required plots from empty state-owned lands... and allowing other interested colonists to create settlements there." ${ }^{37}$ Although the Volga colonists received the right to live in the Caucasus in $1838,{ }^{38}$ not all of them did so legally.

High birth rates in the colonies together with the practice of ultimogeniture (the youngest child inherits the farm) and the lack of free land caused unemployment among youth rise dramatically. By 1855, the colonies of the Southern Krai had anannual growth rate of 28.5 people per 1,000, and in the Bessarabia Region the rate was 17.3. ${ }^{39}$ This explains why unauthorized outmigration grew among the colonists.

Officials introduced various measures attempting to address such problems. For example, the Germans of the Ribensdorf colony in Voronezh Province were permitted to move to the Eisk region, while Volga Germans were allowed set up factories in the colonies. ${ }^{40}$ But if they moved to another province without permission, they "were deprived... of the colonist status, forever lost the rights and benefits granted with the status and were re-registered in other taxable estates on a common basis." ${ }^{41}$

The Volga scholar E.V. Ananian rightly concludes that the migration of Germans from their Saratov colonies was prompted not only by land hunger but also by the gradual

34 “O pereselenii 124 semeystv Chernigovskikh kolonistov v Yekaterinoslavskuyu guberniyu № 4616," in Polnoe sobranie zakonov Rossiyskoy imperii. Collection 2. Partition 1. Vol. 16, (St. Petersburg: Tipografiya II Otdeleniya Sobstvennoy E. I. V. Kantselyarii Press., 1842), 421.

35 "Ob opredelenii v okrugi Saratovskikh koloniy osobykh Smotriteley; i o vospreshchenii tamoshnim kolonistam perekhodit' v drugiye mesta bez razresheniya Nachal'stva № 30.537," in Polnoe sobranie zakonov Rossiyskoy imperii. Collection 1. Vol. 11, 534-535.

36 “O samovol'nom poselenii kolonistov v 1809/10 gg. pishut starshina kolonii Karras A. Paterson i sovetskiy issledovatel' S.A. Chekmenev," in Akty, sobrannye Kavkazskoy Arkheograficheskoy komissiey (Tiflis: [S.n.], 1873), 910; S.A. Chekmenev, "Inostrannye poseleniya na Stavropol'e v kontse XVIII i pervoy polovine XIX v.” In Materialy po izucheniyu Stavropol'skogo kraya, (Stavropol': [B.i.] 1971), 245.

37 "Kavkazskaya oblast'," Akty, sobrannye Kavkazskoy Arkheograficheskoy komissiyey, no. 898 (1878): 939.

38 Ye.V. Ananyan, Nemtsy Povolzh'ya: ot immigratsii $k$ emigratsii (1760-1880-e gg.). Dva s polovinoy veka s Rossiyey (k 250-letiyu nachala massovogo pereseleniya nemtsev v Rossiyu): Materialy 4-y mezhdunarodnoy nauchno-prakticheskoy konferentsii (Moscow: Gotika Publ., 2013), 212.

${ }^{39}$ V.G. Chebotareva, "Nemetskiye kolonii v real'noy situatsii krepostnicheskoy Rossii: politika paternalizma po otnosheniyu k nemetskim krest'yanam." In Nemtsy Rossii: evolyutsiya istoricheskogo puti (1762 g. $X X$ v.) (Moscow: Mezhdunarodnyy Soyuz obshchestvennykh ob"yedineniy nemtsev, Obshchestvennaya akademiya nauk rossiyskikh nemtsev Publ., 2012), 63.

40 “O pereselenii kolonistov kolonii Ribensdorf, Voronezhskoy gubernii, na zemli bliz g. Yeyska v Chernomorii № 26077," in Polnoe sobranie zakonov Rossiyskoy imperii. Collection 2. Partition 1. Vol. 27 (St. Petersburg: Tipografiya II Otdeleniya Sobstvennoy E. I. V. Kantselyarii Press., 1853), 160-162; "O dozvolenii, v vide iz"yatiya, domokhozyayevam Obshchestva kolonii Zoloturn, Nikolayevskogo uyezda, Samarskoy gubernii, uchredit' v oznachennoy kolonii tabachnuyu fabriku № 30.309," in Polnoe sobranie zakonov Rossiyskoy imperii. Collection 2. Partition 1. Vol. 31, 157.

41 "O lishenii kolonistov, samovol'no pereselivshikhsya iz odnoy gubernii v druguyu, prav, predostavlennykh kolonistskomu zvaniyu № 41919, ” in Polnoe sobranie zakonov Rossiyskoy imperii. Collection 2. Partition 1. Vol. 40 (St. Petersburg: St. Petersburg: Tipografiya II Otdeleniya Sobstvennoy E. I. V. Kantselyarii Press., 1867), 315. 
elimination of their privileges. ${ }^{42}$ There was another factor as well-money spent on moving to Russia had to be repaid after the grace period expired. The first settlers to come to the attention of the authorities and ordered to pay their debt and land tax (pozemel'nyi obrok) in 1805 , were the St. Petersburg colonists. ${ }^{43}$ At the end of the same year, the Khortitsa Mennonites were also required to settle their debts, followed by the Josefstal colonists in $1808 .^{44}$

That year, a proposal by Minister of the Interior A.B. Kurakin was approved to collect taxes and debts from the Saratov colonists from 1809 "to encourage them to work harder and practice useful activities in autumn and winter" in the amount of five rubles from those living on the Meadow side of the Volga and three rubles from those on the Hillside. ${ }^{45}$ This was the first move to bring their obligations closer to those of Russian peasants, who paid 6.28 rubles per person registered in the census (revizskaia dusha), ${ }^{46}$ and in 1816 "The taxes of Saratov colonists were aligned with those of state peasants." 47 Similar laws followed for colonists in other Russian provinces.

The second half of the $19^{\text {th }}$ century was once again marked by land hunger in the German colonies as population growth outstripped economic development. To deal with the matter, Volga Germans repeatedly tried to leave their original settlements and establish daughter colonies in other locations. In 1861, according to a decree passed by the Chancellery for Foreign Settlers, the unauthorized resettlement of colonists was considered to be vagrancy and would be severely punished. But this did not stop the colonists. In 1866, the authorities polled colonists who responded that they were aware of the ban on moving to the Caucasus. ${ }^{48}$ Subsequently, the continued scarcity of arable land and numerous appeals led the government to change its mind and allow them to resettle there.

Between the late 1850s and 1870s, the German colonists lost their privileges and were recategorized as belonging to the peasant class. The first move came in 1857 , with the Statute on the Colonies of Foreigners in the Empire, ${ }^{49}$ which designated the territories where German colonists could live. The new law also regulated their civil rights and the management of the colonies but maintained their tax benefits based on the terms and conditions set forth in their charters (zhalovannaia gramota). However, it obligated them to pay land duties (zemskie povinnosti) "on an equal basis with other inhabitants."

In 1866 the responsibility for the German colonies began to be transferred to the regular authorities. ${ }^{50}$ At first, the move affected those in Voronezh, Novgorod, Samara,

${ }^{42}$ E.V. Ananyan, Nemtsy Povolzh'ya, 212.

43 "Ob uravnenii sankt-peterburgskikh koloniy v platezhe dolzhnykh imi v kaznu ssudnykh i pozemel'nykh deneg, sorazmerno ikh sostoyaniyu № 21.837,” in Polnoe sobranie zakonov Rossiyskoy imperii. Collection 1. Vol. 28, 1128-1131.

44 “O vzyskanii kazennogo dolga s Khortitskikh menonistov i Iozefstal'skikh kolonistov, i o platezhe imi pozemel'nykh deneg № 21909," in Polnoe sobranie zakonov Rossiyskoy imperii. Collection 1. Vol. 28, $1241-1243$.

45 “'O raznykh rasporyazheniyakh kasatel'no podatey, vzyskivayemykh s kolonistov, poselivshikhsya na zemlyakh Saratovskoy gubernii № 23.408," in Polnoe sobranie zakonov Rossiyskoy imperii. Collection 1. Vol. 26, 731 .

46 “Ob uravnenii sankt-peterburgskikh koloniy v platezhe dolzhnykh imi v kaznu ssudnykh i pozemel'nykh deneg, sorazmerno ikh sostoyaniyu № 21.837," in Polnoe sobranie zakonov Rossiyskoy imperii. Collection 1. Vol. 28, 730 .

47 “O sravnenii Saratovskikh kolonistov v platezhe podatey s kazennymi krest'yanami № 26.013," in Polnoe sobranie zakonov Rossiyskoy imperii. Collection 1. Vol. 33, 398.

${ }^{48}$ Gosudarstvenny arkhiv Saratovskoy oblasti, f. 180, op. 4, d. 35.

49 "Ustav o koloniyakh inostrantsev v imperii," in Polnoe sobranie zakonov Rossiyskoy imperii. Collection 2. Partition 1. Vol. 31, 3-90.

50 "O peredache koloniy inostrannykh poselentsev v vedeniye obshchikh po krest'yanskim delam uchrezhdeniy № 44000," in Polnoe sobranie zakonov Rossiyskoy imperii. Collection 2. Partition 1. Vol. 41 (St. Petersburg: Tipografiya II Otdeleniya Sobstvennoy E. I. V. Kantselyarii Press., 1868), 408. 
St. Petersburg and Chernigov Provinces, and led to a new wave of migration of those who refused to accept the inferior status of the peasantry to the Caucasus, Don Host Oblast and Novorossiisk Krai.

The government attempted to stabilize the situation by abolishing the Saratov Chancellery for Foreign Settlers and the Guardianship Committee for Foreign Settlers of the Southern Region of Russia, which were the special offices to issue passports to the colonists. ${ }^{51}$ Nevertheless, the most enterprising as well as landless colonists still sought to leave the colonies and obtained their documents in district and rural administrative offices (prikazy).

\section{The beginning of the emigration movement of German colonists}

On June 4, 1871, the implementation of the "Rules for the Migration of Landowning Settlers" drastically changed the lives of the colonists ${ }^{52}$ by downgrading their social status and eliminating self-government. At the same time, the former colonists were granted the right to re-register in another estate in the next ten years or "renounce allegiance to Russia and leave it without paying a portion of the capital they accumulated to the Treasury." 53 Not everyone wanted to become an ordinary peasant, and "viewed this an encroachment on their privileges and began to leave Russia on a massive scale." 54

In 1874 the colonists - including the Mennonites - lost their most important privilege when the Law of Universal conscription made them eligible for military service as well ${ }^{55}$. At the same time, new regulations also affected their faith. Rather than only resettle in remote Central Asian regions, the Germans also reacted by emigrating from Russia. The Don Host Oblast's administration reported:

In the Miusskii District alone, from 1875 to 1887 , up to 40 land transfers to companies of German settlers were registered. ${ }^{56}$

As for the Volga Germans and Novorossiia, in addition to land hunger, publicity from colonists who had already emigrated to North America and Brazil also encouraged many to follow suit. For example, in discussions with the Brazilian embassy in St. Petersburg, representatives of the former said that 30,000 fellow colonists wanted to go to that country. ${ }^{57}$ According to Governor N.A. Durnovo, more than one thousand families from the Khortitskaia Volost (a unit of peasants' local self-rule) in Ekaterinoslav Province left for America. ${ }^{58}$

51 “O poryadke vydachi pasportov inostrannym poselentsam № 45922," in Polnoe sobranie zakonov Rossiyskoy imperii. Collection 2. Partition 1. Vol. 43 (St. Petersburg: Tipografiya II Otdeleniya Sobstvennoy E. I. V. Kantselyarii Press., 1873), 685.

52 "Pravila ob ustroystve poselyan-sobstvennikov (byvshikh kolonistov), vodvorennykh na kazennykh zemlyakh v guberniyakh: S.-Peterburgskoy, Novgorodskoy, Samarskoy, Saratovskoy, Voronezhskoy, Chernigovskoy, Poltavskoy, Yekaterinoslavskoy, Khersonskoy i Tavricheskoy i v oblasti Bessarabskoy № 49705," in Polnoe sobranie zakonov Rossiyskoy imperii. Collection 2. Partition 2. Vol. 46 (St. Petersburg: Tipografiya II Otdeleniya Sobstvennoy E. I. V. Kantselyarii Press.,1874), 813-819.

53 Ibid., 817.

${ }^{54}$ M.I. Mysh', Ob inostrantsakh v Rossii. Sbornik ukazaniy, traktatov, konventsiy s pravitel'stvennymi i sudebnymi raz"yasneniyami (St. Petersburg: N.A. Lebedev Press., 1888), 11.

55 “O vvedenii vseobshchey voinskoy povinnosti № 52983,” in Polnoe sobranie zakonov Rossiyskoy imperii. Collection 2. Partition 1. Vol. 49 (St. Petersburg: Tipografiya II Otdeleniya Sobstvennoy E. I. V. Kantselyarii Press., 1876), 2-29.

56 O.V. Erokhina, Nemetskiye kolonii Oblasti Voyska Donskogo (vtoraya polovina XIX v. - fevral' 1917 g.) (Volgograd: Volgogradskoye nauchnoye izdatel'stvo Publ., 2009), 32.

57 A. Eisfeld, "Migration der Russlanddeustchen in der Epoche von der Gründung des Deutschen Reiches bis zur Auflösung der Sowjetunion," 67.

58 O.V. Erokhina, "Forest teams - an alternative Mennonite service in the Russian Empire until 1914," Science Journal of Volgograd State University. History. Area Studies. International Relations 24, no. 3 (2019): 72. 
Most emigrants were Mennonites whose religious beliefs forbade military service. They set out for Argentina and the United States as rumors about the impending reform began to circulate. In 1873, about 900 families (approximately 4,500 people) left two volosts in the Tauride Province alone. ${ }^{59}$

Not only individual Mennonite families, but entire colonies and volosts left the country, selling their lands and property. For example, the inhabitants of the Alexanderpol colony in the Halbstadt Volost and the entire Bergtal Volost in the Mariupol Uezd sailed to America. ${ }^{60}$ "The Upper Mennonites" migrated to America as early as in 1874, leaving their homesteads to German Lutherans. ${ }^{61}$ According to L. V. Malinovskii, the Germans and Mennonites

were unable to sell their plot and homestead to a non-colonist, thus damaging the social homogeneity and ethnic isolation of the German village. ${ }^{62}$

A year later, the State Council amended Article 157 of the Statute on Conscription to free the Mennonites from carrying weapons. However, they were still obligated to noncombat service in the workshops of the Maritime Department, fire brigades, and in special mobile teams of the Forestry Department. Despite the concessions, Germans and Mennonites continued to migrate and emigrate.

Alexander III enacted new restrictions on the German colonists in the SouthWestern Krai, which only led more of them to move. Attracted by uncultivated land and low prices, already in the 1860s, some Germans had emigrated from the Kingdom of Poland to Volyn. If in 1860, 11,424 Germans lived in the province, by 1890 there were 200,924. Their large numbers in the empire's vulnerable border areas caused much concern in the war ministry, which reacted by fomenting hysteria about the "German domination" in the press that resulted in legislation not only to restrict the flow of immigrants, but also forced Germans to leave the region.

The first step came on November 1, 1886, when Western Krai's government was authorized to issue land purchase certificates at its discretion. ${ }^{63}$ On March 14, 1887, foreign nationals were forbidden to acquire real estate in 10 western Russian provinces. ${ }^{64}$ As a result, German colonists were forced to become Russian subjects to keep their property. Officials then liquidated their self-government by integrating them with local peasants and townspeople. ${ }^{65}$ And the final blow was delivered by the laws of March 14, 1892 and March 19, 1895, which forbade foreign nationals from settling in the Volyn Province outside of its towns as well as forbidding new migrants from owning land. ${ }^{66}$

German colonists also saw the subordination of colonial schools to the Ministry of Public Education in 1890, mandatory teaching in Russian in their schools seven years,

59 A.A. Velitsyn, Nemtsy $v$ Rossii. Ocherki istoricheskogo razvitiya $i$ nastoyashchego polozheniya nemetskikh koloniy na yuge i vostoke Rossii (St. Petersburg: Russkiy vestnik Publ., 1893), 162-163.

${ }^{60}$ S.D. Bondar', Sekta mennonitov v Rossii. V svyazi s istoriyey nemetskoy kolonizatsii v Rossii (Petrograd: V.D. Chernov Press., 1916), 39.

${ }^{61}$ M. Kostyuk, D. Noytatts, "Volynskiye nemtsy," in Nemtsy Rossii: Entsiklopediya (Moscow: Obshchestvennaya akademiya nauk rossiyskikh nemtsev Publ., 1999), 395.

${ }^{62}$ L.V. Malinovskiy, Istoriya nemtsev v Rossii (Barnaul: BGPU Publ., 1995), 178.

63 “O vvedenii vseobshchey voinskoy povinnosti № 52983," in Polnoe sobranie zakonov Rossiyskoy imperii. Collection 2. Partition 1. Vol. 49, 470.

64 “'Ob ob"yavlenii vsekh svidetel'stv, vydannykh do izdaniya pravil 27 dekabrya 1884 goda na pokupku imeniy v Zapadnom kraye, poteryavshimi svoyu silu № 3985," in Polnoe sobranie zakonov Rossiyskoy imperii. Collection 3. Vol. 6 (St. Petersburg: Gosudarstvennaya tipografiya, 1886), 101-102.

65 "Ob ustroystve byta inostrannykh poselentsev, vodvorivshikhsya v guberniyakh: Kiyevskoy, Podol'skoy i Volynskoy № 5357," in Polnoe sobranie zakonov Rossiyskoy imperii. Collection 3. Vol. 8 (St. Petrsburg: Gosudarstvennaya tipografiya, 1888), 409-411.

66 “O poryadke vydachi pasportov inostrannym poselentsam № 45922," in Polnoe sobranie zakonov Rossiyskoy imperii. Collection 2. Partition 1. Vol. 43, 142-143. 
as well as the requirement to maintain book-keeping in Russian as forced "Russification." ${ }^{67}$ Furthermore, Germans were forced to move to Siberia, Central Asia, the Don, or emigrate to America. Nevertheless, they did manage to establish new communities in some regions of Asian Russia, where they adapted to new conditions and became successful farmers and entrepreneurs. ${ }^{68}$

\section{Conclusion}

The Russian Empire's migration policy was largely shaped by economic and political considerations. Until the middle of the 19th century, the autocracy needed to populate and develop the country's borderlands, which was impossible to accomplish by relying solely on the internal population. As a result, it invited foreigners, primarily from the German states, through a consistent policy of incentives. However, until 1914, the government's inability to alleviate the colonists' economic difficulties, withdrawal of benefits and privileges, as well as growing hostility between Russia and Germany encouraged many to resettle elsewhere in the empire and eventually leave it altogether.

The migrations of German colonists to and within the Russian Empire were complex, multi-dimensional social phenomena, and cannot be analyzed using a one-sided approach. Instead, there were different stages and types of migration, including immigration to Russia from the German states, resettlement within the empire, and emigrations abroad much like those in the $20^{\text {th }}$ century as a result of the Civil War, evictions, deportations, and the return of Volga Germans to their ancestral fatherland. All types of their migration can also be classified according to their causes, whether initiated by the state (both voluntary and forced), unorganized, and voluntary, as well as on the reasons for resettlement, including politics, economics and religion.

In short, migration among the Russian Germans was a multi-dimensional phenomenon that fits several models simultaneously and that had a major impact on how their diaspora evolved, as well as on the social structure of the colonists. Although at various times the state tried to control such migration for political and economic reasons, it was unable fully to do so fully. The movements of Russian German communities resembled those of other ethnic groups and regions. However, they also had distinct political, economic, and social characteristics.

Рукопись поступила: 4 марта 2020 г.

Submitted: 4 March 2020.

\section{References}

Ananyan, Ye.V. Nemtsy Povolzh'ya: ot immigratsii k emigratsii (1760-1880-ye gg.). Dva s polovinoy veka $s$ Rossiey (k 250-letiyu nachala massovogo pereseleniya nemtsev v Rossiyu): Materialy 4-y mezhdunarodnoy nauchno-prakticheskoy konferentsii. Moscow: Gotika Publ., 2013 (in Russian).

Bondar', S.D. Sekta mennonitov v Rossii. V svyazi s istoriyey nemetskoy kolonizatsii v Rossii. Petrograd: Tipografiya V.D. Chernova Press, 1916 (in Russian).

Bosch, A. Geschichte in Gedichten und Prosa. Auswanderung aus Franken an die Wolga. Nürnberg: [S.n.], 2018 (in German).

Chebotareva, V.G. "Nemetskiye kolonii v real'noy situatsii krepostnicheskoy Rossii: politika paternalizma po otnosheniyu k nemetskim krest'yanam.” In Nemtsy Rossii: evolyutsiya istoricheskogo

67 “O poryadke vydachi pasportov inostrannym poselentsam № 45922," in Polnoe sobranie zakonov Rossiyskoy imperii. Collection 2. Partition 1. Vol. 43, 245.

${ }^{68} \mathrm{~V}$. Shaidurov, "The German catholic community of Marienburg from the end of the $19^{\text {th }}$ till the beginning of the $20^{\text {th }}$ century: some aspects of the local history," Rusin, no. 2 (2018): 288-308; V. Shaidurov, "German industrial enterprises in Western Siberia in the second half of the $19^{\text {th }}$ century," Bylye gody 43, no. 1 (2017): 162-168. 
puti (1762 g. - XX v.), 13-79. Moscow: Mezhdunarodnyy Soyuz obshchestvennykh ob"yedineniy nemtsev, Obshchestvennaya akademiya nauk rossiyskikh nemtsev Publ., 2012 (in Russian).

Chekmenev, S.A. "Inostrannye poseleniya na Stavropol'ye v kontse XVIII i pervoy polovine XIX v." In Materialy po izucheniyu Stavropol'skogo kraya, 243-253. Stavropol': [S.n.] 1971 (in Russian).

Chernova-Doke, T.N. Nemetskiye poseleniya na periferii Rossiyskoy imperii: Kavkaz: vzglyad skvoz' stoletiye (1818-1917). (K 190-letiyu osnovaniya nemetskikh koloniy). Moscow: Mezhdunarodnyy soyuz nemetskoy kul'tury Publ., 2008 (in Russian).

Eisfeld, A. "Migration der Russlanddeustchen in der Epoche von der Gründung des Deutschen Reiches bis zur Auflösung der Sowjetunion." In Die Russlanddeutschen in den Migrationsprozessen zwischen den GUS-Staaten und Deutschland, 65-115. Göttingen: Göttinger Arbeitskreis, 2008 (in German).

Erokhina, O.V. "Forest teams - an alternative Mennonite service in the Russian Empire until 1914." Science Journal of Volgograd State University. History. Area Studies. International Relations 24, no. 3 (2019): 68-78. DOI: 10.15688/jvolsu4.2019.3.6 (in Russian).

Erokhina, O.V. Nemetskiye kolonii Oblasti Voyska Donskogo (vtoraya polovina XIX v. - fevral' 1917 g.). Volgograd: Volgogradskoye nauchnoye izdatel'stvo Publ., 2009 (in Russian).

Funk, W. "Deutsche als russische Kolonisten." In Blätter für fränkische Familienkunde, 101-124. Nürnberg: [S.n.], 1929 (in German).

Gal'perina, Yu.S. "Economic development of the German colonies on the Volga in the second half of XVII - the first half of the XX century." Saratov University Bulletin. History. International relationships 14, no. 3 (2014): 98-103 (in Russian).

German, A.A., and Pleve, I.R. Nemtsy Povolzh'ya: kratkiy istoricheskiy ocherk. Saratov: Izd-vo Saratovskogo universiteta Publ., 2002 (in Russian).

Klaus, A. Nashi kolonii. Opyty $i$ materialy po istorii i statistiki inostrannoy kolonizatsii $v$ Rossii. St. Petersburg: V.V. Nusval't Press., 1869 (in Russian).

Kostyuk, M., and Noytatts, D. "Volynskiye nemtsy." In Nemtsy Rossii: Entsiklopediya, 395-399. Moscow: Obshchestvennaya akademiya nauk rossiyskikh nemtsev Publ., 1999 (in Russian).

Larina, O., and Shaidurov, V. "European diasporas in Russia of the late $18^{\text {th }}$ and early $19^{\text {th }}$ centuries: National and regional formation features (as illustrated in the case of Jews, Germans and Poles)." Mediterranean Journal of Social Sciences 6, no. 5 (2015): 460-466. DOI:10.5901/mjss.2015. v6n5s $1 \mathrm{p} 460$.

Lindeman, K.E. Prekrashcheniye zemlevladeniya i zemlepol'zovaniya poselyan-sobstvennikov. Ukazy 2 i 13 dekabrya 1915 g. i 10, 15 iyulya i 19 avgusta 1916 g. i ikh vliyaniye na ekonomicheskoye sostoyaniye yuzhnoy Rossii. Moscow: K.L. Men'shov Press., 1917 (in Russian).

Litzenberger, O. Deutsche evangelische Siedlungen an der Wolga. Nürnberg: [S.n.], 2013 (in German).

Litzenberger, O. Deutsche katholische Siedlungen an der Wolga. Nürnberg: [S.n.], 2018 (in German).

Lyubavskiy, M.K. Obzor istorii russkoy kolonizatsii. Moscow: Izd-vo Moskogo universiteta Publ., 1996 (in Russian).

Malinovskiy, L.V. “Obshchina nemetskikh kolonistov v Rossii i yeye regional'nyye osobennosti v XIX nachale XX veka.” Istoriya SSSR, no. 2 (1992): 175-182 (in Russian).

Malinovskiy, L.V. Istoriya nemtsev v Rossii. Barnaul: BGPU Publ., 1995 (in Russian).

Mysh', M.I. Ob inostrantsakh v Rossii. Sbornik ukazaniy, traktatov, konventsiy s pravitel'stvennymi $i$ sudebnymi raz"yasneniyami. St. Peterburg: N.A. Lebedev Press., 1888 (in Russian).

Pisarevskiy, G.G. Izbrannyye proizvedeniya po istorii inostrannoy kolonizatsii v Rossii. Moscow: MSNK Publ., 2011 (in Russian).

Pleve, I.R. "Priyem inostrannykh kolonistov v Rossii i otpravka k mestu poseleniya v 60-kh godakh XVIII v." In Migratsionnye protsessy sredi rossiyskikh nemtsev: istoricheskiy aspect, 13-26. Moscow: Gotika Publ., 1998 (in Russian).

Shaidurov, V. "German industrial enterprises in Western Siberia in the second half of the $19^{\text {th }}$ century." Bylye gody 43, no. 1 (2017): 162-168.

Shaidurov, V. "The German catholic community of Marienburg from the end of the $19^{\text {th }}$ till the of the $20^{\text {th }}$ century: some aspects of the local history." Rusin, no. 2 (2018): 288-308. DOI: 10.17223/ $18572685 / 52 / 20 /$.

Stach, J. Die deutschen Kolonisten in Süd-Russland. Prischib: [S.n.], 1904 (in German).

Stumpp, K. "Die deutsche Auswanderung nach Russland, 1763-1862." In Heimatbuch der Ostumsiedler, 162-171. Stuttgart: [S.n.], 1961 (in Russian).

Vashkau, N.E. Shkola v nemetskikh koloniyakh Povolzh'ya. 1764-1917. Volgograd: Izd-vo Volgogradskogo gos. un-ta Publ., 1998 (in Russian). 
Velitsyn, A.A. Nemtsy v Rossii. Ocherki istoricheskogo razvitiya i nastoyashchego polozheniya nemetskikh koloniy na yuge i vostoke Rossii. St. Petersburg: Russkiy vestnik Publ., 1893 (in Russian).

Venger, N.V. Mennonitskoye predprinimatel'stvo v usloviyakh modernizatsii yuga Rossii: mezhdu kongregatsiyey, klanom i rossiyskim obshchestvom (1789-1920). Dnepropetrovsk: Izd. Dnepropetrovskogo nats. un-ta Publ., 2009 (in Russian).

\section{Библиографический список}

Ананян Е.В. Немцы Поволжья: от иммиграции к эмиграции (1760-1880-е гг.). Два с половиной века с Россией (к 250-летию начала массового переселения немцев в Россию): Материалы 4-й международной научно-практической конференции. М.: Готика, 2013. 320 с.

Бондарь С.Д. Секта меннонитов в России. В связи с историей немецкой колонизации в России. Петроград: Тип. В.Д. Чернова, 1916. 208 с.

Вашкау Н.Э. Школа в немецких колониях Поволжья. 1764-1917. Волгоград: Изд-во Волгогр. Гос. ун-та, 1998. 208 с.

Велицын А.А. Немцы в России. Очерки исторического развития и настоящего положения немецких колоний на юге и востоке России. СПб.: «Русский вестник», 1893. 282 с.

Венгер Н.В. Меннонитское предпринимательство в условиях модернизации юга России: между конгрегацией, кланом и российским обществом (1789-1920). Днепропетровск: Изд. Днепропетровского нац. ун-та, 2009. 696 с.

Гальперина Ю.С. Хозяйственное развитие немецких колоний на Волге во второй половине XVIII первой половине XIX века // Известия Саратовского университета. История. Международные отношения. 2014. Т. 14. № 3. С. 98-103.

Герман А.А., Плеве И.Р. Немцы Поволжья: краткий исторический очерк. Саратов: Изд-во Сарат. ун-та, 2002. $144 \mathrm{c.}$

Ерохина O.B. Лесные команды - альтернативная служба меннонитов в Российской империи до 1914 года // Вестник Волгоградского государственного университета. Серия 4. История. Регионоведение. Международные отношения. 2019. Т. 24. № 3. С. 68-78. DOI: 10.15688/ jvolsu4.2019.3.6.

Ерохина O.B. Немецкие колонии Области Войска Донского (вторая половина XIX в. - февраль 1917 г.). Волгоград: Волгоградское научное издательство, 2009. 195 с.

Клаус A. Наши колонии. Опыты и материалы по истории и статистики иностранной колонизации в России. СПб.: тип. В.В. Нусвальта, 1869. 102 с.

Костюк М., Нойтати Д. Волынские немцы // Немцы России: Энциклопедия. М.: Общественная академия наук российских немцев, 1999. С. 395-399.

Линдеман К.Э. Прекращение землевладения и землепользования поселян-собственников. Указы 2 и 13 декабря 1915 г. и 10, 15 июля и 19 августа 1916 г. и их влияние на экономическое состояние южной России. М.: Тип. К.Л. Меньшова, 1917. 384 с.

Любавский М.К. Обзор истории русской колонизации. М.: Изд-во Моск. ун-та, 1996. 682 с.

Малиновский Л.В. История немцев в России. Барнаул: БГПУ, 1995. 181 с.

Малиновский Л.В. Община немецких колонистов в России и ее региональные особенности в XIX начале XX века // История СССР. 1992. № 2. С. 175-182.

Мышь М.И. Об иностранцах в России. Сборник указаний, трактатов, конвенций с правительственными и судебными разъяснениями. СПб.: Тип. Н.А. Лебедева, 1888. 532 с.

Писаревский Г.Г. Избранные произведения по истории иностранной колонизации в России / Г.Г. Писаревский. М.: МСНК, 2011. 224 с.

Плеве И.Р. Прием иностранных колонистов в России и отправка к месту поселения в 60-х годах XVIII в. // Миграционные процессы среди российских немцев: исторический аспект. М.: Готика, 1998. С. 13-26.

Чеботарева В.Г. Немецкие колонии в реальной ситуации крепостнической России: политика патернализма по отношению к немецким крестьянам // Немцы России: эволюция исторического пути (1762 г. - XX в.). М.: Международный Союз общественных объединений немцев, Общественная академия наук российских немцев, 2012. С. 13-79.

Чекменев C.A. Иностранные поселения на Ставрополье в конце XVIII и первой половине XIX в. // Материалы по изучению Ставропольского края. Ставрополь: [Б.и.] 1971. С. 243-253.

Чернова-Дёке Т.Н. Немецкие поселения на периферии Российской империи: Кавказ: взгляд сквозь столетие (1818-1917). (К 190-летию основания немецких колоний) / Т.Н. Чернова-Дёке. М.: Международный союз немецкой культуры, 2008. 208 с. 
Bosch A. Geschichte in Gedichten und Prosa. Auswanderung aus Franken an die Wolga. Nürnberg: [S.n.], 2018. 444 p.

Eisfeld A. Migration der Russlanddeustchen in der Epoche von der Gründung des Deutschen Reiches bis zur Auflösung der Sowjetunion // Die Russlanddeutschen in den Migrationsprozessen zwischen den GUS-Staaten und Deutschland. Göttingen: Göttinger Arbeitskreis, 2008. P. 65-115.

Funk W. Deutsche als russische Kolonisten // Blätter für fränkische Familienkunde. Nürnberg: [S.n.], 1929. P. 101-124.

Larina $O$., Shaidurov $V$. European diasporas in Russia of the late $18^{\text {th }}$ and early $19^{\text {th }}$ centuries: National and regional formation features (as illustrated in the case of Jews, Germans and Poles) // Mediterranean Journal of Social Sciences. 2015. Vol. 6. № 5. P. 460-466. DOI:10.5901/mjss. 2015.v6n5s $1 \mathrm{p} 460$.

Litzenberger O. Deutsche evangelische Siedlungen an der Wolga. Nürnberg: [S.n.], 2013. 704 p.

Litzenberger O. Deutsche katholische Siedlungen an der Wolga. Nürnberg: [S.n.], 2018. 676 p.

Shaidurov $V$. The German catholic community of Marienburg from the end of the $19^{\text {th }}$ till the beginning of the $20^{\text {th }}$ century: some aspects of the local history // Rusin. 2018. № 2. P. 288-308. DOI: $10.17223 / 18572685 / 52 / 20 /$.

Shaidurov $V$. German industrial enterprises in Western Siberia in the second half of the $19^{\text {th }}$ century $/ /$ Bylye gody. 2017. Vol. 43 № 1. P. 162-168. DOI: 10.13187/bg.2017.1.162.

Stach J. Die deutschen Kolonisten in Süd-Russland. Prischib: [S.n.], 1904. 26 p.

Stumpp K. Die deutsche Auswanderung nach Russland, 1763-1862 // Heimatbuch der Ostumsiedler. Stuttgart: [S.n.], 1961. P. 162-171.

\section{Информация об авторах / Information about the authors}

Ерохина Ольга Викторовна, доктор исторических наук, профессор кафедры истории России Московского педагогического государственного университета.

Ольга Андреевна Лиценбергер, доктор исторических наук, профессор, научный сотрудник Баварского центра культуры немцев из России.
Olga V. Erokhina, Doktor Istoricheskikh Nauk [Dr. habil. hist.], Professor of the Chair of the History of Russia, Moscow Pedagogical State University.

Olga A. Litzenberger, Doktor Istoricheskikh Nauk [Dr. habil. hist.], Professor, Research Scientist of the Bavarian Cultural Centre for Germans from Russia. 